\title{
Latin Politics,
}

Global Media 



\section{Latin Politics,}

\section{Global Media}

Elizabeth Fox and Silvio Waisbord, Editors

\UNIVERSITY OF TEXAS PRESS, AUSTIN 
Copyright $\left({ }^{2} 2002\right.$ by the University of Texas Press

All rights reserved

Printed in the United States of America

First edition, 2002

Requests for permission to reproduce material from this work should be sent to Permissions, University of Texas Press, Box 7819, Austin, TX 787I3-78I9.

@ 0 The paper used in this book meets the minimum requirements of ANSI/NISO Z39.48-I992 (RI997)

(Permanence of Paper).

Library of Congress Cataloging-in-Publication Data

Latin politics, global media / Elizabeth Fox and Silvio Waisbord, editors. - Ist ed.

p. $\mathrm{cm}$.

Includes bibliographical references and index.

ISBN 0-292-72536-I (alk. paper) -

ISBN 0-292-72537-X (alk. paper)

I. Mass media-Political aspects-Latin America. 2. Mass media policy-Latin America. 3. Latin

America-Politics and government-I980- I. Fox, Elizabeth (Fox de Cardona) II. Waisbord, Silvio R.

(Silvio Ricardo), I96I-

P95.82.L29 L38 2002

$302.23^{\prime} 098-\mathrm{dc} 2 \mathrm{I}$

2001048064 
To Mariorie Ferguson, who demystified globalization, and to José Antonio Mayobre, who lived within its paradoxes, in memoriam 